\title{
United States - Definitive Safeguard Measures on Imports of Circular Welded Carbon Quality Line Pipe From Korea Not for Attribution*
}

\author{
BY \\ GENE M. GROSSMAN \\ Princeton University \\ AND \\ PETROS C. MAVROIDIS \\ University of Neuchâtel and Columbia University
}

\section{Facts of the Case}

This dispute concerns the imposition of a definitive safeguard measure by the United States on imports of circular welded carbon quality line pipe ("line pipe") from Korea (WTO DOC. WTO/DS 202/AB/R). The measure was imposed following an investigation conducted by the US International Trade Commission (USITC). The USITC determined in a safeguard investigation initiated on 29 July 1999 that "circular welded carbon quality line pipe... is being imported into the United States in such increased quantities as to be a substantial cause of serious injury or the threat of serious injury." In its investigation, the USITC identified a

* This study reviews the WTO Appellate Body report United States - Definitive Safeguard Measures on Imports of Circular Welded Carbon Quality Line Pipe From Korea (WT/ DS202/AB/R 15 February 2002). We are grateful to Henrik Horn and Jasper-Martijn Wauters for helpful discussions and to Alan Sykes, whose paper (Sykes, 2003) profoundly influenced our thinking about these issues.

1 The Appellate Body report on United States - Definitive Safeguard Measures on Imports of Circular Welded Carbon Quality Line Pipe From Korea (WT/DS202/AB/R 15 February 2002; henceforth, Line Pipe) that we discuss in this paper notes (p. 1) that three Commissioners made a finding of serious injury, two Commissioners made a finding of threat of serious injury and that the affirmative vote of these five Commissioners 
number of factors apart from increased imports that might have caused serious injury or threat of serious injury to the domestic line pipe industry. The Commission concluded that increased imports were "a cause which is important and not less than any other cause" and that, therefore, the statutory requirement of "substantial cause" had been met. ${ }^{2}$

By Proclamation of the President of the United States dated 11 February 2000, the United States imposed a definitive safeguard measure on imports of line pipe in the form of a duty increase for three years applicable to imports above 9,000 short tons from each source country, effective 1 March 2000. ${ }^{3}$ The applicable duty was increased by 19 percent ad valorem in the first year, 15 percent in the second year, and 11 percent in the third year. The measure was applied to imports from all countries, including Members of the World Trade Organization (WTO), but excluding imports from Canada and Mexico, the NAFTA partners of the United States.

Korea requested consultations with the United States pursuant to Article 4 of the Understanding on Rules and Procedures Governing the Settlement of Disputes (DSU), Article XXII:1 of the General Agreement on Tariffs and Trade 1994 (GATT) and Article 14 of the Agreement on Safeguards (SGA), with regard to the safeguard measures on line pipe. ${ }^{4}$ When the two sides failed to resolve a number of disputed issues, Korea requested that a WTO panel be established to examine US actions in this case. The Panel concluded that the US safeguard measure for line pipe was inconsistent with certain of the provisions of the GATT and the SGA. ${ }^{5}$ The Panel found, inter alia, that the United States had acted inconsistently with Article 4.2(b) of the SGA by failing to establish a causal link between the increased imports and serious injury to a domestic industry, or threat thereof. The Panel however rejected an argument by Korea that the United States had acted inconsistently with its obligations under Art. 5.1 of the SGA by imposing a safeguard measure intended to

constituted the majority in support of the "affirmative determination" of the USITC. A single Commissioner made a negative determination that there was neither serious injury nor threat of serious injury. The views of that Commissioner are not part of the USITC determination.

2 See Line Pipe at p. 2.

3 "Proclamation 7274 of 18 February 2000 - To Facilitate Positive Adjustment to Competition From Imports of Certain Circular Welded Carbon Quality Line Pipe," United States Federal Register, 23 February 2000 (Volume 65, Number 36), pp. 9193-9196; Panel Report, para. 7.176, also reflected on p. 3 of the $\mathrm{AB}$ report on Line Pipe.

${ }^{4}$ WTO Doc. WT/DS202/1, G/L/388, G/SG/D10/1, 15 June 2000.

${ }^{5}$ WTO Doc. WT/DS202/5, 22 January 2001. 
counteract the whole of the injury suffered by the import-competing industry rather than only the part that could be attributed to increased imports.

Both the United States and Korea appealed aspects of the Panel's ruling. The United States claimed inter alia that the Panel was wrong in its ruling about causality, because the USITC had explicitly addressed that issue and had found that imports were a substantial cause of serious injury, meaning a "cause that is important and no less so than any other cause." Korea argued inter alia that the Panel had erred in sanctioning a safeguard measure meant to offset the entire injury to the industry and not just the part due to increased imports. In this chapter, we will focus on just these two issues and not on a number of relatively less important questions that were also in dispute.

The remainder of the chapter is organized as follows. In Section 2, we describe the relevant legal provisions in the GATT and the SGA and the prior WTO jurisprudence that bears on this case. In Section 3, we discuss the possible objectives of the escape clause in the GATT and the SGA. Ideally, we would hope to use the objectives of the agreement to inform our interpretation of the treaty text. However, we will argue that the parties' intentions in these agreements are by no means clear. Section 4 outlines in greater detail the issues concerning attribution of injury and the extent of safeguard measures that are at issue in this case. Here, we also recount the Panel and $A B$ rulings. Section 5 contains our critique of the $\mathrm{AB}$ ruling. We argue that a redrafting of the relevant provisions of the GATT and the SGA is badly needed. We summarize and conclude in Section 6.

\section{Relevant Legal Provisions and Prior Jurisprudence}

\subsection{The relevant provisions of GATT and SGA}

The WTO treaty allows a signatory to abrogate its obligations to other Members for a proscribed period of time under certain conditions. The conditions describe changes in the health of a domestic industry that competes directly with imports (i.e., that produces a "like product") and the causes of those changes. In particular, Article XIX.1a of the GATT states that

If, as a result of unforeseen developments and of the effect of the obligations incurred by a Member under this Agreement, including tariff concessions, any product is being imported into the territory of that Member in such 
increased quantities and under such conditions as to cause or threaten serious injury to domestic producers in that territory of like or directly competitive products, the Member shall be free, in respect of such product, and to the extent and for such time as may be necessary to prevent or remedy such injury, to suspend the obligation in whole or in part or to withdraw or modify the concession.

The SGA provides further detail on the nature of the investigation that must be used to determine injury, the nature of the required link between imports and injury, and on many procedural matters. ${ }^{6}$ Among the provisions that are germane to this case is Article 2.1 of the SGA, which stipulates that

A Member may apply a safeguard measure to a product only if that Member has determined, pursuant to the provisions set out below, that such product is being imported into its territory in such increased quantities, absolute or relative to domestic production, and under such conditions as to cause or threaten to cause serious injury to the domestic industry that produces like or directly competitive products.

\section{Article $4.2 \mathrm{a}$ of the SGA adds that}

In the investigation to determine whether increased imports have caused or are threatening to cause serious injury to a domestic industry under the terms of this Agreement, the competent authorities shall evaluate all relevant factors of an objective and quantifiable nature having a bearing on the situation of that industry, in particular, the rate and amount of the increase in imports of the product concerned in absolute and relative terms, the share of the domestic market taken by increased imports, changes in the level of sales, production, productivity, capacity utilization, profits and losses, and employment.

Finally, Article 4.2b requires that

The determination referred to in [Article 4.2a] shall not be made unless this investigation demonstrates, on the basis of objective evidence, the existence of the causal link between increased imports of the product concerned and serious injury or threat thereof. When factors other than increased imports are causing injury to the domestic industry at the same time, such injury shall not be attributed to increased imports.

(emphasis added)

${ }^{6}$ In Argentina - Safeguard Measures On Imports Of Footwear (WTO Doc. WT/DS121/AB/R of 14 December 1999) and elsewhere the $A B$ has ruled that safeguard measures must be consistent with both Article 19 of GATT and the SGA; see paras. 83, 84, 93 and 94. 
Concerning the dispute over the nature and extent of the US safeguard measure, the relevant text is contained in the first sentence of Article 5.1 of the SGA. This sentence reads that

A Member shall apply safeguard measures only to the extent necessary to prevent or remedy serious injury and to facilitate adjustment.

\subsection{Prior WTO case law}

The $\mathrm{AB}$ has not as yet attempted to define what the treaty requires as a standard for "serious injury," nor has it delineated the factors that should be considered as possible contributors to that injury. Concerning Article 4.2 of the SGA, where it states that "the competent authorities shall evaluate all relevant factors of an objective and quantifiable nature having a bearing on the situation of that industry, in particular, the rate and amount of the increase in imports of the product concerned in absolute and relative terms, the share of the domestic market taken by increased imports, changes in the level of sales, production, productivity, capacity utilization, profits and losses, and employment," the $\mathrm{AB}$ has ruled in Argentina - Safeguard Measures on Imports of Footwear (WT/DS121/AB/ R 14 December 1999; henceforth Footwear) that the text requires that the entire list of factors must be "evaluated" in every case. Also, in United States - Definitive Safeguard Measures on Imports of Wheat Gluten From the European Communities (WT/DS166/AB/R 22 December 2000; henceforth Wheat Gluten), the $\mathrm{AB}$ has ruled that an investigating authority faced with multiple potential causes of injury must, in accordance with Article 4.2a of the SGA, examine every factor known to it and not only those raised by the interested parties. ${ }^{7}$

${ }^{7}$ Para. 55 of Wheat Gluten states, in part, that:

"... in our view, that does not mean that the competent authorities may limit their evaluation of 'all relevant factors', under Article 4.2(a) of the Agreement on Safeguards, to the factors which the interested parties have raised as relevant. The competent authorities must, in every case, carry out a full investigation to enable them to conduct a proper evaluation of all of the relevant factors expressly mentioned in Article 4.2(a) of the Agreement on Safeguards. Moreover, Article 4.2(a) requires the competent authorities and not the interested parties - to evaluate fully the relevance, if any, of 'other factors'. 
Much of the argumentation in disputes concerning the use of safeguard measures has centered on the meaning of the words "cause" and "causal" in Article XIX.1 of the GATT and Articles 2.1 and 4.2 of the SGA, and on the meaning of the requirement in Article 4.2b of the SGA that, in situations where it is deemed that factors other than increased imports have contributed to an industry's ill health, "such injury shall not be attributed to increased imports." The AB has indicated in United States Safeguard Measures On Imports Of Fresh, Chilled Or Frozen Lamb Meat From New Zealand And Australia (WTO Doc. WT/DS177 and 178/AB/R of 1 May 2001; henceforth Frozen Lamb) that it considers a two-step analysis to be appropriate: first, the competent authority must ensure that injury due to other factors is not attributed to imports and then it must find evidence of a causal link between increased imports, and injury. The $\mathrm{AB}$ wrote in para.180 of Frozen Lamb:

... the 'causal link' between increased imports and serious injury can only be made after the effects of increased imports have been properly assessed, and this assessment, in turn, follows the separation of the effects caused by all the different causal factors.

(emphasis in the original)

The $\mathrm{AB}$ has not been at all clear about what a competent authority must do to comply with the requirement that injury due to "other factors" should not be attributed to increased imports. For example, in Wheat Gluten (para. 70) the AB ruled that

The need to ensure a proper attribution of injury under Article 5.2(b) indicates that competent authorities must take account, in their determination, of the effects of increased imports as distinguished from the effects of other factors.

(emphasis in the original)

while in Frozen Lamb (para. 181) the AB wrote:

We emphasize that the method and approach WTO Members choose to carry out in the process of separating the effects of the other causal factors is not specified by the Agreement on Safeguards. What the Agreement requires is simply that the obligation in Article 4.2 must be respected when a safeguard measure is applied.

Nonetheless, the $\mathrm{AB}$ has repeatedly found fault with investigations carried out by the competent authorities, especially the USITC, ruling on several occasions that they have failed to comply with the requirement for nonattribution. In Wheat Gluten (para. 19), the AB concluded that the USITC 
had not "adequately evaluated the complexities" and had not "ensured that injury attributable to other factors is not attributed to imports." In Frozen Lamb, the AB wrote (para. 185) that

... we see nothing in the USITC Report to indicate how the USITC complied with the obligation found in the second sentence of Article 4.2(b) and, therefore, we see no basis for either the Panel or us to assess the adequacy of the USITC process with respect to the "nonattribution" requirement of Article 4.2(b) of the Agreement on Safeguards. The USITC Report, on its face, does not explain the process by which the USITC separated the injurious effects of the different causal factors, nor does the USITC Report explain how the USITC ensured that the injurious effects of the other causal factors were not included in the assessment of the injury ascribed to increased imports.

and (para. 186)

In the absence of any meaningful explanation of the nature and extent of the injurious effects of these six 'other' factors, it is impossible to determine whether the USITC properly separated the injurious effects of these other factors from the injurious effects of the increased imports. It is, therefore, also impossible to determine whether injury caused by these other factors has been attributed to increased imports.

If an investigating authority somehow could convince the $A B$ that it had met the requirements for non-attribution, it seems it could rather more easily meet the standards for establishing causality. In principle, the $\mathrm{AB}$ recognizes the distinction between correlation and causation; for example, in Footwear (para. 144) it concurred with the Panel that "coincidence by itself cannot prove causation." But, in practice, the AB has not grappled much with the difficulty of demonstrating causal relationships between economic events. Rather, it has been content to accept co-temporal movements (i.e., correlation) as evidence of causality in most situations. In Footwear, the $\mathrm{AB}$ noted in para. 141 that "if causation is present, an increase in imports normally should coincide with a decline in the relevant injury factors" and in para. 144 it concurred with the Panel that

... in an analysis of causation, 'it is the relationship between the movements in imports (volume and market share) and the movements in injury factors that must be central to a causation analysis and determination.' (emphasis added) Furthermore, with respect to a 'coincidence' between an increase in imports and a decline in the relevant injury factors, we note that the Panel simply said that this should 'normally' occur if causation is present. 
Although the $\mathrm{AB}$ has been adamant about the need for an investigating authority to separate the injury caused by increased imports from those caused by other factors, it has ruled that the SGA does not require that the authority show that increased imports alone would have been sufficient to cause serious injury. To the contrary, the AB stressed in Frozen Lamb (para. 70) that

... the Agreement on Safeguards does not require that increased imports be 'sufficient' to cause, or threaten to cause, serious injury. Nor does the Agreement require the increased imports 'alone' be capable of causing, or threatening to cause, serious injury.

To summarize, the $\mathrm{AB}$ has noted the distinction between causation and correlation, but has not provided guidance on how the two should be distinguished in practice. The $\mathrm{AB}$ has insisted that the Members ensure that injury caused by other factors not be attributed to increased imports, but has not suggested an acceptable method for ensuring non-attribution. And the $\mathrm{AB}$ has indicated that an import surge normally should be contemporaneous with injury to the domestic industry, but has ruled that the surge need not be sufficient to have caused serious injury without other, contributing factors.

\subsection{Discussion of previous jurisprudence}

The $\mathrm{AB}$ rulings prior to Line Pipe create a number of difficult problems for this and subsequent interpretation of the Safeguards Agreement. The difficulties have been rehearsed at length by Horn and Mavroidis (2003), Sykes (2003), Irwin (2003), and others, so the discussion here can be reasonably brief.

First, the $\mathrm{AB}$ has failed in all of its rulings to confront the meaning of the words "cause" and "causal" as they apply in the context of safeguard proceedings. This is very problematic, because the text makes clear the need to establish that increased quantities of imports have been a cause of serious injury to the domestic industry and yet, as Grossman (1986), Kelly (1988), Rousslang (1988), Horn and Mavroidis (2003), Sykes (2003), Irwin (2003), and others have argued, the volume of imports of a particular product into a particular country is an endogenous outcome that cannot logically be considered to be the cause of other economic outcomes. That is, a number of supply and demand factors combine to determine equilibrium outcomes in an industry. Among these are the factor and input prices faced by national and foreign producers, the 
technologies available for producing the good at home and abroad, consumers' tastes for the goods produced by the industry, the prices of goods produced by competing industries, the overall levels of demand in the national and international economies, etc. These factors jointly determine the location of the supply and demand curves for the product of the import-competing industry and the supply and demand curves for imports. The supplies and demands in turn determine the sales of the national industry, the prices of national and imported products, and (importantly!) the volume of imports. Thus, a change in the underlying conditions of supply or demand will affect not only the health of the domestic industry (sales, employment, profits, rates of return on capital, etc.) but also the quantity of imports. So, it is simply impossible to ascribe a causal relationship between an increased quantity of imports and injury to a domestic industry when the two outcome variables are determined simultaneously by the same set of fundamental variables. Yet, this is exactly what Article XIX of the GATT and Article 4.1 of the SGA requires the competent authority in a safeguard investigation to do.

Sykes (2003) has argued that the historical context of the GATT gives some hints as to what the negotiating parties might have meant by their wording of the text. At the time that they wrote that "If, as a result of unforeseen developments and of the effect of the obligations incurred by a contracting party under this agreement, including tariff concessions, any product is being imported into the territory of that contracting party in such increased quantities and under such conditions as to cause or threaten serious injury..." the multilateral tariff reductions that were being considered by the parties were unprecedented and so their likely consequences were unknown. It makes sense in this context that the negotiating parties might have intended to draw a link between the "effects of the obligations incurred by a contracting party under this agreement" and the "increased quantities" of imports that might "cause or threaten serious injury." In other words, it is possible to interpret the sentence as meaning that the investigating authorities should look not for a causal relationship between increased imports per se and the conditions of the domestic industry (which would be impossible), but rather between the increased imports that resulted from the obligations incurred in the 1947 GATT Agreement and the injury that might result soon thereafter as a direct consequence thereof.

However, the wording has remained unchanged for fifty-six years and it is no longer sensible to look for injury caused by obligations incurred in 1947. Moreover, the $\mathrm{AB}$ has ruled explicitly that the requirement that 
injury be a result of "the obligations incurred by a contracting party under this agreement, including tariff concessions" means only that the importing party must have taken on some obligations as a result of its participation in the trade treaties. ${ }^{8}$ As Sykes (2003) concludes, and we agree, the passage of time and the $\mathrm{AB}$ interpretation of the first clause of Article XIX of the GATT combine to eliminate the possibility of an economically coherent interpretation of the entire sentence. If it is not increased imports resulting from some specific exogenous event that is considered to be a possible cause of injury, but rather increased imports as a whole, then it is logically impossible to perform the separation of causes stipulated by the non-attribution provisions of the SGA.

It is not surprising, then, that the $\mathrm{AB}$ has failed to provide any clear guidance about what sort of analysis would qualify to meet its requirements for non-attribution. While the $\mathrm{AB}$ insists that the investigating authorities must provide a "reasoned and adequate explanation" (Frozen Lamb at para. 103) for their conclusion that injury due to other factors has not been attributed to an increase in imports, no such explanation is possible in the absence of a coherent interpretation of what it means for imports to cause injury.

\subsection{The legal context for Line Pipe: summary}

The discussion of causality and non-attribution in the Line Pipe dispute takes place in the context of a deeply flawed legal environment. Concerning the text of the pertinent agreements, Sykes (2003, p. 21) summarizes well:

... it is important to focus on the fundamental problem: neither Article XIX nor the Safeguards Agreement offer a coherent foundation for safeguard measures. The Appellate Body has consistently emphasized fidelity to text in its decisions, but that approach simply cannot work when the text is so fundamentally deficient.

Moreover, the prior case law has done little to resolve the questions raised by the text and much to add uncertainty about what an investigating

${ }^{8}$ Another interpretation with some intellectual appeal would be to read Article XIX of the GATT as providing an instrument to compensate losses that might result from the most recent round of trade liberalization. Such an interpretation suffers, however, from at least two important shortcomings: first, the language to support this interpretation is absent from the text of the SGA and Article XIX of the GATT; second, such an interpretation would deprive Members of the right to introduce safeguards when imports surge in sectors in which tariffs were not reduced in the most recent trade round. 
authority must do to fulfill its obligations to its WTO partners in safeguard proceedings. Evidently, such an authority must (i) examine all relevant factors that may have affected conditions in an industry, including those not raised by the interested parties themselves, (ii) establish the existence of serious injury by examining (at least) all of the industry factors mentioned in Article 4.2a of the SGA, (iii) provide an explicit, reasoned and adequate explanation for how it has distinguished the injury caused by increased imports from the injury caused by other factors, and (iv) determine that increased imports bear a causal relationship to deteriorating industry conditions at least by showing co-movement of these variables. How it can do so in a world where imports and industry conditions are simultaneously determined by other exogenous factors remains unclear.

\section{Possible Objectives of the Safeguards Agreement}

Before we proceed to our discussion of the issues concerning causality and non-attribution that arise in Line Pipe, we pause to consider the objectives of the Safeguards Agreement. As we argued in Grossman and Mavroidis (2003), it is important to understand the objectives of an agreement and what behaviors it is meant to discourage or tolerate in order to interpret the meaning of the text and discern how it ought to be applied in circumstances that are not explicitly discussed. Unfortunately, we will find in this case that the objectives of the agreement are no more clear than is the text or the prior case law. Although there are several possible economic rationales for including an escape clause in a multilateral trade agreement, the Safeguards Agreement is not structured in a way that indicates any particular one of them as the intended or proper purpose. Accordingly, economic theory provides relatively little guidance as to how the Agreement ought to be interpreted when adjudicating disputes.

\subsection{Safeguards as compensation for losers}

The opening of trade via multilateral negotiations will generate aggregate efficiency gains in many situations, but there are bound to be individuals and groups that are harmed. The inclusion of safeguard measures in a trade agreement might be rationalized as a means to compensate the losers from trade liberalization (see Deardorff, 1987). A safeguard measure can be used to restore relative prices to what they would have been 
but for the trade liberalization and thereby preserve jobs and incomes for workers in the import-competing industry. To the extent that the protection is temporary, the compensation will only be partial. But the burdens imposed on displaced workers might be mitigated if these workers have a longer period to retrain and seek new employment.

However, as Burtless et al. (1998), Sykes (2003), and many others have argued, trade protection is a clumsy tool for effecting redistribution. Empirical studies have found repeatedly that import-restraining policies impose very high costs on the importing country per job saved or per dollar transferred due to the productive inefficiencies that result from such measures and the great burdens they impose on consumers (see, for example, Feenstra (1992)). The total cost of these measures is even larger when the interests of the exporting country are taken into account, as they presumably will be in any negotiated agreement. Protectionist responses are poorly targeted policies for the purposes of effecting redistribution to disadvantaged groups inasmuch as they boost incomes not only of displaced workers and others with specific human capital, but also of welldiversified (and often quite wealthy) shareholders who own the firms and capital in the import-competing industry. Also, it is hard to see why a society would find it desirable to compensate the losses from unexpected import surges, but not those resulting from other economic events that affect the fortunes of individuals working in or invested in a particular industry.

There is nothing explicit in the way that the text of GATT Article XIX or the SGA is written to suggest that the intended purpose of the safeguard provisions is to compensate the losers from trade liberalization. First, the preferred interpretation of Article XIX of the GATT that has been offered by the $\mathrm{AB}$ does not limit the use of safeguards measures to situations in which losses are attributable to trade liberalization per se, but rather to import surges that occur for any reason. Second, Article XXVIII of the GATT, which provides for renegotiation of concessions, would seem a preferable tool for protecting the interests of those that are harmed by trade protection, inasmuch as such renegotiation allows for a more permanent restoration of competitive conditions to what they were before the tariff concessions or other effects of an agreement. Third, as Sykes has argued, the text of Article XIX of the GATT limits application of safeguards to injury that results from "unforeseen developments"; if redistribution were the rationale for these provisions, it is difficult to see why the Members would not have wished also to compensate losers also for the anticipated consequences of their trade concessions. 


\subsection{Safeguards to promote restructuring or facilitate adjustment}

3.2.1 Promoting investments to restore competitiveness Industry representatives often seek to justify their pleas for escape clause protection on the grounds that such measures will provide the wherewithal for reinvestment and restructuring to restore competitiveness. Temporary protection can increase profitability so that firms have more funds available to invest in retooling, while the respite from foreign competition can give them time for their new investments to come on line. In this way, proponents argue, viable firms can be saved when otherwise they might be driven from the market by cheap imports.

Although this argument may resonate with some politicians and lay persons, it makes little economic sense. Firms that are viable in the long run should be able to finance their investments in restructuring by borrowing funds or raising equity in the capital markets. For an investment to be socially warranted, it must yield expected discounted profits (or other social benefits) at free-market prices that equal or exceed the cost of the project plus any risk premium. Firms with potential projects that meet this criterion should be able to borrow at prevailing interest rates, unless there are imperfections in the capital market. Those that do not meet the criterion and that become profitable only with the help of elevated prices during a period of import protection should be rejected as economically inefficient. And capital markets, at least in the developed countries, are widely thought to be reasonably efficient, at least in most cases. Even if they are not, a targeted program that would provide subsidized capital or loan guarantees to firms and industries that are unable to obtain financing at socially appropriate rates would be a far superior policy to one of protection, which affects the allocation of all resources and not just capital, and which imposes avoidable burdens on domestic consumers.

If Article XIX of the GATT and the Safeguards Agreement were intended to promote investments in restructuring, one would expect to find certain provisions in them that are missing. Investments in restructuring ought to be limited to cases in which the domestic industry is viable in the long run, and in which the private capital markets would charge an unjustifiable premium to firms attempting to raise external funding. Thus, a test for the applicability of safeguards would begin with an examination of whether the conditions in the domestic industry have changed temporarily or permanently, and whether new investments 
reasonably could be expected to restore profitability. It would also include an investigation to establish the existence of capital market imperfections that prevent the domestic industry from financing profitable investments by borrowing or issuing new shares. It might reasonably include a requirement that trade policies be used only when less trade distorting measures (such as credit subsidies or loan guarantees) are unavailable. Finally, it might include provisions to ensure that the excess profits generated from the temporary protection are in fact invested in restructuring and not used to generate windfall gains to shareholders and bondholders. Article XIX of the GATT and the SGA contain none of these features.

\subsubsection{Promoting efficient adjustment}

Safeguard measures might also be rationalized as a means to promote efficient and orderly reallocation of resources (especially labor) in situations in which adjustment is costly. As Mussa $(1982,1984)$ has shown, the mere fact that resource movements are costly provides no presumption that a free-market adjustment process will be inefficient. If workers have rational expectations about the future of their industry and have access to capital markets to finance temporary income shortfalls at interest rates close to the social discount rate, and if real wages are reasonably flexible and an individual's job search creates no externalities for others, then workers will move from a declining industry to another (and bear the associated costs of search and re-training) at the rate that is socially warranted. Of course, labor markets may be distorted due to the existence of short-run wage rigidities or congestion in the search process. Then, as Lapan (1976), Neary (1982), Cassing and Ochs (1978) and Davidson and Matusz (2001) have shown, the free-market rate of adjustment can easily be too rapid, with excessive unemployment or sub-optimal matching of workers to jobs.

Horn and Mavroidis (2003) have built a case for including safeguard provisions in trade agreements around the presence of distortions in the labor market. ${ }^{9}$ They describe a situation in which an unanticipated, permanent shift in the foreign supply curve of imports indicates a decline in the efficient, long-run employment level in a domestic industry. Following such a shock, a temporary safeguard measure could be expected to raise social welfare if the size of total adjustment costs depends positively on the speed of adjustment, and if there is a gap between the private and social

\footnotetext{
9 See also Sykes (1991) and, for a more formal treatment, Davidson and Matusz (2002).
} 
costs of adjustment. The positive link between the speed of adjustment and the size of adjustment costs would arise, for example, if wages are inflexible, so that a fall in labor demand results in displacements rather than wage cuts, and if the number of workers that can be absorbed by new employers rises gradually over time. In such circumstances, with unemployment caused by wage rigidities rather than optimal search for new employment, the private and social costs of unemployment are bound to diverge.

Horn and Mavroidis (2003) note some potential pitfalls in the use of safeguard measures to promote more efficient adjustment, which might account for some of the features of Article XIX of the GATT and the SGA. First, governments might be tempted to invoke safeguard protection any time they feel political pressure from special interests in an industry, and not just in response to shocks that necessitate fine-tuning of the adjustment process. A test for serious injury might be incorporated into the safeguard provisions as a means to discourage such opportunistic behavior. Also, if safeguard measures could be invoked to cushion any negative shocks, firms in the domestic industry might face insufficient incentives to exercise due diligence in avoiding unnecessary job displacements. To eliminate this moral hazard for the domestic industry, the escape clause provisions could require a causal link between external events and injury to the industry, and preclude the use of safeguard measures when the need for adjustment is entirely due to the poor performance of domestic firms.

While the adjustment-cost rationale for safeguard provisions is consistent with certain features of the WTO Safeguards Agreement, it is hard to interpret the Agreement as a whole as being a response to this particular economic problem. First, as Horn and Mavroidis (2003) themselves point out, a protectionist measure is hardly a first-best response to the labor market imperfection that they (and others) have identified. It would be far more efficient to treat adjustment problems with a program of "adjustment assistance" that would provide income insurance for displaced workers plus worker training and perhaps some wage subsidies. In fact, empirical studies by Hufbauer and Elliot (1994), Sazanami et al. (1995), Messerlin (2001), among many others, suggest that, in practice, the costs of trade protection in a variety of countries far outweigh the possible efficiency gains attainable from slowing the rate of worker relocation. Second, as Sykes (2003) points out, a safeguard provision intended to promote more efficient adjustment would include an investigation of industry conditions to determine whether they suggest that it would be 
beneficial to stretch out the adjustment process. At the least, a high rate of industry unemployment might seem a sensible pre-requisite for safeguard measures intended to slow the departure of workers from an industry. But the SGA explicitly requires that competent authorities examine a variety of indicators of industry health and not just unemployment. Third, the SGA has no provisions to ensure that adjustment actually takes place during the period of temporary protection. Indeed, many industries have used safeguard protection as a way to avoid contraction, and many have returned for second and third doses of "temporary" relief after having failed to adjust.

\subsection{Safeguards as political safety valves}

A third possible objective of the safeguard provision in trade agreements is to serve as a political safety valve. If a Member knows that it can "escape" from its commitments in the face of intense political pressures, it may be willing to make greater concessions in its multilateral negotiations than would be the case if its liberalization was irreversible. Moreover, if an agreement gives a Member the option to roll back prior concessions in times of political need, this may dissuade the Member from resorting to extra-legal measures or from scrapping the agreement altogether. This rationale for safeguard provisions has been developed most fully by Sykes (1991, 2003), who goes on to argue that "serious injury" might be a proxy for intense political pressure in the importing country, while increased quantities of imports suggest that the foreign industry is not suffering similarly. Sykes suggests that when an import surge coincides with serious injury to an industry in an importing country, safeguard measures might be used to create surplus for the two governments, inasmuch as the government in the importing country could gain more political support from a market-closing measure than the other would lose.

To some extent, it is tautological to argue that safeguard provisions have been included in trade agreements to provide a political safety valve. The provisions would not be part of the agreement had the negotiators not perceived that allowing them to be invoked in certain circumstances would create political surplus for the Member governments. The issue of concern is whether taking this perspective provides guidance on how the treaty text ought to be interpreted. Surely, Members cannot be allowed to escape from the agreement any time they claim a political benefit from doing so, for this would invite opportunistic behavior and would in no 
way ensure that the provisions are invoked only when the political gains to the government of the importing country exceed the losses to those of the exporting country. And whereas Sykes (2003) argues that "serious injury" and correlation of injury with increased imports suffices to identify the relevant circumstances, we question whether this is so. Grossman and Helpman (1994) show, for example, that access to a foreign market may be especially valuable to special interests in an exporting industry when those firms are highly productive and enjoy low costs. In such circumstances, a safeguard measure might impose greater political costs on the government of the exporting country than it provides benefits to that of the importing country. ${ }^{10}$

In short, it is not enough to recognize that the safeguard provisions are intended as a political safety valve to be invoked whenever the continued application of bound tariffs would cause more political harm to the government of the importing country than would their temporary suspension cause to the government of the exporting country, for this would amount to a legal test with little if any normative guidance, and hence would be unsuitable in the context of international adjudication. We, as interpreters of the agreement, still need to know how the negotiating parties meant to identify such circumstances and what limitations they intended to impose on the importing country to protect the political interests of the government of the exporting country. In reviewing this and other potential objectives of the safeguard provisions, we find little to guide us in interpreting the language of the text or in adjudicating disputes such as Line Pipe. The SGA is silent about what the Members intended to achieve by their incorporation of safeguard provisions in the trade treaty.

We are thus faced with a situation in which an agreement that is opaque about its intended objectives contains an incoherent conditions test. Under the circumstances, it is almost impossible for us to render a cogent interpretation of the text that could be used to determine when safeguard measures are permissible and when they are not. But this question is the essence of the Line Pipe dispute, to which we now turn.

${ }^{10}$ Sykes argues that when exporters are especially profitable, the special interests in the exporting industry will not value market access highly, because any potential rents will be dissipated by entry; see also Baldwin and Robert-Nicoud (2001). But this argument rests on the assumption that there are no quasi-fixed factors of production in the industry that might limit entry and thereby create rents for those who have entered first. 


\section{Issues and Rulings in Line Pipe}

\subsection{USITC investigation and findings}

The safeguard provisions in US trade law are contained in Sections 201 to 204 of the Trade Act of 1974. These Sections allow interested parties in an import-competing industry to petition the USITC requesting an investigation as to whether a product is being imported into the United States in such increased quantities as to be a substantial cause of serious injury, or threat thereof, to the domestic industry producing an article that is like or directly competitive with the imported article. The statute defines a "substantial cause" to be a "cause which is important and not less than any other cause." It defines "serious injury" as a "significant overall impairment in the position of a domestic industry." Sections 201 to 204 do not require that injury be linked to any trade liberalization or concessions made by the United States in an international agreement, nor do they stipulate any explicit effort on the part of the USITC to ensure that injury caused by other factors is not attributed to increased imports.

The USITC instituted a Section 201 investigation of line pipe on 30 June 1999 following receipt of a petition from seven domestic producers and the United Steelworkers of America. As required by US law, the Commissioners considered whether the domestic industry producing line pipe had suffered serious injury or threat thereof, and if so, whether increased imports were a substantial cause of that injury. In their report of December 1999, the Commission reported its findings that there were increased quantities of imports during the five years preceding the investigation, that the domestic industry had suffered serious injury, and that imports were a substantial cause of that injury. ${ }^{11}$ In making its determination of serious injury, the Commission considered a variety of indicators of industry conditions, including all of those listed in Article 4.2a of the SGA. As possible causes of injury, the Commission considered the role of increased imports, of decline in the demand for line pipe due to reduced oil and natural gas drilling, of competition among domestic producers, of changes in the market for oil country tubular goods (also produced by domestic producers of line pipe) that may have caused domestic line pipe producers to switch production out of these goods,

11 Three commissioners found that the industry had suffered serious injury, two found that the industry was threatened by serious injury, and one found that there had been no injury. According to USITC rules, this constitutes a finding in favor of serious injury. 
of contraction in US producers' export markets, of increase in per-unit overhead resulting from shrinking production, and of declines in raw material costs. The Commission ruled that the decline in demand for line pipe resulting from reduced oil and natural gas drilling and production activities indeed had contributed to the industry's poor performance, but that the effects of increased imports on the domestic industry were as great or greater. It also ruled that the other factors either had no adverse effect on the industry, or had an effect that was very much smaller than that of imports. Finally, concerning the attribution of injury to its various causes, the Commissioners wrote: ${ }^{12}$

\begin{abstract}
Respondents also argued that we may not attribute injury caused by [the other] factors to the imports. We have not done so. As required by the statute, after evaluating all possible causes of injury, we have determined that the imports are an important cause of serious injury and are not less important than any other cause.
\end{abstract}

In the light of its positive finding that increased imports were a substantial cause of serious injury to the domestic line pipe industry, the USITC recommended various remedies to the President of the United States. The President introduced a safeguard measure by proclamation, without providing an explicit justification for the extent of the measure or any evidence that the measure was limited to that which was necessary to address the injury that could be attributed to increased imports.

\title{
4.2 The Panel ruling
}

A WTO Panel was established on 23 October 2000 to consider complaints by Korea regarding the line pipe measure. Korea argued before the Panel inter alia that the USITC had violated its obligations under Article $4.2 \mathrm{~b}$ of the SGA by failing to demonstrate properly that injury caused by other factors had not been attributed to increased imports. In particular, Korea asserted that the USITC had not properly distinguished the injurious effects caused by other factors from those caused by imports and thus it could not assure the non-attribution required by Article 4.2b of the SGA. Korea also claimed that the United States had violated its obligations contained in Article 5.1 of the SGA to ensure that its safeguard measure was applied "only to the extent necessary to prevent or remedy serious

12 See the USITC investigation of Circular Welded Carbon Quality Line Pipe (USITC Investigation No. TA-201-70, Publication 3261, December 1999) at p. I-30. 
injury and to facilitate adjustment." Korea contended that a safeguard measure must be limited in size to at most what would counteract the injurious effects of the increased imports. According to Korea, because the USITC had not ensured that injury caused by other factors was not attributed to increased imports, it could also not ensure that the safeguard measures introduced subsequently were applied only to the extent necessary to offset the injury attributable to imports.

The Panel ruled in favor of Korea on the first point, rejecting in the process the US argument that the USITC had properly distinguished the effects of other factors from the effects of increased imports by examining six factors other than increased imports as possible causes of serious injury and determining that none was a more important cause of injury. The Panel concluded on this point that the USITC "did not adequately explain how it ensured that injury caused to the domestic industry by factors other than increased imports was not attributed to increased imports." 13

The Panel rejected Korea's claims about the permissible extent of the safeguard measure, ruling that it had failed to make a prima facie case showing that the United States had violated Article 5.1 of the SGA. The Panel noted (para. 7.11) that "Korea has failed to identify any aspect of the line pipe measure which would suggest that it was intended to address the injurious effects of the decline in the oil and gas industry" and added that even had the remedy recommended by the USITC been intended to do so, this did not mean that the line pipe measure that was eventually applied by the United States was illegal, because the latter differed substantially from the remedy recommended by the Commission. The panel concluded that "[s]ince Korea has failed to establish any factual basis for its argument, it is not necessary for us to consider the substantive issue of whether or not safeguard measures should be confined to addressing the injurious effects of imports." Evidently, the Panel did not find merit in Korea's claim that the failure by the USITC to distinguish the injury due to other factors from that due to increased imports implies, as a matter of logic, that the United States could not have succeeded in limiting the extent of the safeguard measure so as to counteract only the injurious effects of the increased imports.

13 See United States - Definitive Safeguard Measures on Imports of Circular Welded Carbon Quality Line Pipe From Korea (WT/DS202/R 29 October 2001) at para. 7.290. 


\subsection{Appellant arguments and the AB ruling}

The United States appealed the Panel's ruling on non-attribution, arguing that the Panel had simply presumed without any factual analysis that the USITC had not complied with Article $4.2 \mathrm{~b}$ of the SGA in this case. This presumption, the United States claimed, was based on a misinterpretation by the Panel of the AB rulings in Frozen Lamb and Wheat Gluten. The United States contended that the USITC had in fact identified and distinguished the effects of other factors and did not attribute injury caused by those factors to imports, but that the Panel failed to acknowledge or review those findings and analysis. In the view of the United States, the Panel had simply assumed that the USITC's relative injury causation analysis could not possibly have entailed separation and assessment of the injurious effects of factors other than imports, because the methods used in the case were similar to those found faulty in previous cases.

Korea appealed the Panel's ruling on the proportionality of the line pipe measure on the basis that the Panel had failed to recognize a link in the SGA between the causation analysis that a competent authority must perform in order to justify the use of a safeguard measure and the permissible extent of that measure. According to Korea, the SGA limits the extent of a safeguard measure to that which would offset the serious injury attributable to increased imports. If the USITC had failed to ensure that injury due to other factors was not attributed to increased imports, it must have also failed to ensure that the safeguard measure was applied only to the extent of the injury that could be attributed to the increased imports.

The $A B$ upheld the ruling of the Panel on the issue of non-attribution. Essentially, the $\mathrm{AB}$ found that the US analysis of causation did not provide a reasoned and adequate explanation of how it had ensured that injury caused by other factors had not been attributed to increased imports. First, the $\mathrm{AB}$ reiterated its understanding of the requirements imposed by Article $4.2 \mathrm{~b}$ of the SGA:

We have previously ruled, and we reaffirm now, that, to fulfill this requirement, competent authorities must separate and distinguish the injurious effect of the increased imports form the injurious effects of the other factors. As we ruled in US - Hot-Rolled Steel with respect to the similar requirement in Article 3.5 of the Anti-Dumping Agreement, so, too, we are of the view that, with respect to Article 4.2(b), last sentence, competent authorities are required to identify the nature and extent of the injurious effects of the known factors other than increased imports, as well as explain satisfactorily 
the nature and extent of the injurious effects of those other factors as distinguished from the injurious effects of the increased imports.

(para. 215)

Accordingly, the AB noted,

... competent authorities must establish explicitly, through a reasoned and adequate explanation, that injury caused by factors other than increased imports is not attributed to increased imports. This explanation must be clear and unambiguous. It must not merely imply or suggest an explanation. It must be a straightforward explanation in express terms.

(para. 217)

The AB accepted Korea's argument that, although the USITC had recognized that a decline in oil and gas drilling and production had caused injury to the domestic line pipe industry, it had not explicitly identified the nature and extent of the injury attributable to this cause and so it could not have properly separated and distinguished these effects from the effects of increased imports. The $\mathrm{AB}$ concluded that

Our examination [of the US appellant's submissions and of the cited parts of the USITC report] leads us to conclude that those cited parts of the USITC report do not establish explicitly, with a reasoned and adequate explanation, that injury caused by factors other than the increased imports was not attributed to increased imports. The passage on page I-30 of the USITC report highlighted by the United States is but a mere assertion that injury caused by other factors is not attributed to increased imports. A mere assertion such as this does not establish explicitly, with a reasoned and adequate explanation, that injury caused by factors other than the increased imports was not attributed to increased imports. This brief assertion in the USITC Report offers no reasoning and no explanation at all, and therefore falls short of what we have earlier described as a reasoned and adequate explanation.

(para. 220, emphasis in the original)

Apparently, the $\mathrm{AB}$ ruling compels the competent authorities to provide a full accounting of the causes of all injury suffered by an industry to establish explicitly that the injury attributed to imports does not include parts due to other causes.

The $\mathrm{AB}$ also ruled in favor of Korea on the issue it raised concerning the permissible extent of the safeguard measure. The $\mathrm{AB}$ first emphasized that the treaty allows only limited safeguard measures, namely those that are "necessary to prevent or remedy serious injury and facilitate adjustment." 
Since the measures are limited to what is necessary to achieve a certain objective, it becomes imperative to identify the objective. The answer clearly is to offset serious injury, but which serious injury? The $A B$ answers its own question, when it opines that

[i]n our view, the 'serious injury' to which Article 5.1, first sentence, refers is, in any particular case, necessarily the same 'serious injury' that has been determined to exist by competent authorities of a WTO member pursuant to Article 4.2. We think it reasonable to assume that, as the Agreement provides only one definition of 'serious injury', and as the Agreement does not distinguish the 'serious injury' to which Article 5.1 refers from the 'serious injury' to which Article 4.2 refers, the 'serious injury' in Article 5.1 and the 'serious injury' in Article 4.2 must be considered as one and the same. On this, we agree with the United States. But, contrary to what the United States argues, the fact that these two provisions refer to the same 'serious injury' does not necessarily lead to the conclusion that a safeguard measure may address the 'entirety' of the 'serious injury,' including the part of the 'serious injury' that is attributable to factors other than increased imports.

(para. 249)

Next, the $A B$ notes that the meaning of "serious injury" here must be understood in the context of the agreement. The $\mathrm{AB}$ sees the nonattribution language in Article 4.2b of the SGA as a central part of the architecture of the SGA and thus as providing the appropriate context for interpreting Article 5.1 of the SGA. The AB argues that

... the non-attribution language of the second sentence of Article 4.2b has two objectives. First, it seeks, in situations where several factors cause injury at the same time, to prevent investigating authorities from inferring the required 'causal link' between imports and serious injury or threat thereof on the basis of the injurious effects caused by factors other than increased imports. Second, it is a benchmark for ensuring that only an appropriate share of the overall injury is attributed to increased imports. As we read the Agreement, this latter objective, in turn, informs the permissible extent to which the safeguard measure may be applied pursuant to Article 5.1, first sentence. Indeed, as we see it, this is the only possible interpretation of the obligation set out in Article 4.2b, last sentence, that ensures its consistency with Article 5.1, first sentence....

(para. 252)

From this, the $\mathrm{AB}$ concluded that "... the phrase 'only to the extent necessary to prevent or remedy serious injury and to facilitate adjustment' 
in Article 5.1 of the SGA, first sentence, must be read as requiring that safeguard measures may be applied only to the extent that they address serious injury attributed to increased imports" (see para. 261 on p. 83).

\section{Critique of the $\mathrm{AB}$ Rulings}

\subsection{Attributing the causes of injury}

The GATT and the SGA - especially when taken in combination with the prior rulings on escape clause cases by the WTO Appellate Body - do not provide a coherent framework for determining the legality of a safeguard measure. The text requires that the competent authorities find imports to be a cause of serious injury to a domestic industry and that, in so doing, they do not attribute to imports the ill effects of other factors that may be contributing to the industry's poor health. Yet simple economic reasoning reveals that an increased quantity of imports cannot per se be a "cause" of injury, inasmuch as the quantity of imports is determined as an equilibrium outcome along with the various indicators of industry health. For an economic variable to be the "cause" of some effect, it must be possible for that variable to move exogenously and independently of other possible causes. But imports are endogenous, responding as they do to conditions of supply and demand in the domestic and foreign markets. ${ }^{14}$

In principle, it might be possible to ascertain the Members' intended meaning in Article XIX.1 of the GATT and Article 4 of the SGA by considering their objectives in structuring these agreements. But, as we have argued in Section 3 above, the objectives themselves are not clear. The intended role of the safeguard provisions might be to ensure compensation of losers from trade liberalization, to promote efficient readjustment in the face of industry shocks, or to provide a "safety valve" to relieve political pressures. One can readily construct an economic rationale for safeguard provisions that would serve any one of these objectives, but a sensible treaty aiming to achieve each such objective would have to include additional features that are absent from the SGA. Moreover, one would not structure an agreement aimed largely at compensation, for example, in the same way as one intended to promote efficient adjustment. Thus, without knowledge of the primary purpose and intended function of the agreement, one cannot be sure how to structure an

${ }^{14}$ For an elementary exposition of this point, see Kelly (1988) or Horn and Mavroidis (2003). 
appropriate causality test (if, in fact, the inclusion of such a test is indicated at all).

Let us return to the case at hand. In the absence of a clear text and in the light of the jurisprudential history that has involved repeated findings of illegality, it would have behooved the $\mathrm{AB}$ to provide guidance about what sort of investigation would satisfy the requirements of the SGA as currently written. Admittedly, such guidance would only serve as a palliative until the text of the agreement can be improved; but without it, the competent authorities are faced with a text apparently demanding an attribution exercise that cannot meaningfully be performed.

One possible way to lend coherence to Article XIX.1 of GATT and Article 4.1 of the SGA is suggested in a paper by Grossman (1986). In that paper, Grossman confronted the question of how one should interpret the requirement in Section 201 of the US Trade Act of 1974 that safeguard measures be reserved for situations in which increased imports are shown to be a substantial cause of injury to the domestic industry. Since the quantity of imports per se cannot meaningfully be considered to be an exogenous event, Grossman proposed that the USITC seek to identify an event that is "trade-related" and truly exogenous with respect to the health of the domestic industry. A change in trade policy (e.g., a tariff concession) might constitute such an event, but such an interpretation of injury caused by imports would be too narrow in the context of US trade law, because Section 201 makes no reference whatsoever to trade policy when describing the circumstances that would justify a safeguard measure. As an alternative, Grossman noted that a shift in the supply curve of imports is exogenous to the health of the domestic industry and that such a shift could legitimately be considered as a potential cause of injury. ${ }^{15}$ The import supply curve shifts whenever the United States lowers a trade barrier, but also when foreign producers acquire a new technology, become more efficient, experience a fall in factor prices, or install new capacity. Thus, a shift in the import supply curve is distinguished from an increase in the quantity of imports inasmuch as the former reflects events that occur outside the US industry and thus is independent of the "other factors" that impinge upon the industry's health, whereas the latter is the result of events that occur inside the industry as well as those that take place abroad. ${ }^{16}$

${ }^{15}$ See also Kelly (1988), who adopts a similar approach.

${ }^{16}$ Put differently, it is possible to separate the effects of a shift in the import supply curve from the effects of other factors that impact the health of an import-competing industry, 
The "import supply curve" approach lends economic coherence to Section 201 by asking whether changing conditions of import supply, rather than increased quantities of imports, have been a substantial cause of injury to the US industry. ${ }^{17}$ Since a "substantial cause" in the US trade is defined to be a cause that is "important and not less so than any other cause," Grossman proceeds in his paper to enumerate a list of potential exogenous variables that might have caused injury to the US steel industry during the period that he considered, and develops a methodology to compare the amount of injury attributable to each one.

Article XIX.1 of the GATT does not require the competent authorities to show that increased imports have been a substantial cause of injury to a domestic industry. Rather, it requires the authorities to assess whether “... as a result of unforeseen developments and of the effect of the obligations incurred by a Member under this Agreement, including tariff concessions, any product is being imported into the territory of that Member in such increased quantities and under such conditions as to cause or threaten serious injury to domestic producers." It is possible to interpret the exogenous event here as being "the obligations incurred by a Member under this Agreement, including tariff concessions." Indeed, Sykes (2003) suggests that this may have been the meaning intended by the negotiators of the original agreement, wherein "the obligations

as is required to ensure non-attribution. But it is not possible to separate the effects of an increase in the quantity of imports from the effects of these other factors, because the other factors will alter the quantity of imports even as they cause injury to the domestic industry.

17 Sykes (2003) recognizes this virtue of the import supply curve approach, but criticizes it for "effectively rewriting the statute" without providing a legal theory to support its interpretation of the text. We would respond that the incoherence of the text makes some rewriting by the interpreter unavoidable. Absent some imaginative interpretation, the WTO judge would, in the face of the incoherence of the causality-requirement as currently reflected in the SGA, effectively have to deprive WTO Members of the possibility to use safeguards until a new re-negotiated SGA is put in place of the existing text. This would be the case if the WTO judge were to conclude, having exhausted the interpretative elements of Articles 31 and 32 of the Vienna Convention on the Law of Treaties, that the current test is unreasonable or absurd. The other possibility would be for the judge to pick one of the three possible rationales for a safeguards clause that we have advanced supra and define the permissible extent of safeguards by using such a benchmark. Our preferred interpretation can be defended over such an approach with reference to the moral hazard that would exist if domestic factors were to play a role in determining the legitimacy of safeguards. For more on this point, see Horn and Mavroidis (2003). Eventually of course, a clear rewriting of the SGA in this respect has the advantage of providing upfront clarity as to what was actually intended by the Member countries. 
incurred" referred to the entirety of the commitments made under the new treaty. Since the treaty remains in force fifty-six years later, it is no longer possible to associate the "obligations incurred" with the original concessions made in 1947. But the "obligations incurred" might now be read to mean any (or perhaps the most recent) concessions made by a Member of the WTO as a part of the multilateral negotiating process. These policy changes are exogenous events as far as the industry is concerned, and they might give rise to unforeseen developments, including an increase in imports that causes injury.

It would also be possible to take a broader view, such as the one proscribed by the $\mathrm{AB}$. The $\mathrm{AB}$ prefers to read the second part of the first sentence of Article XIX.1 of the GATT (i.e., "the obligations incurred by a Member under this Agreement, including tariff concessions") as providing only the context in which the injury takes place. With this reading, it is not possible to use a change in trade policy as the exogenous event that might precipitate injury. But then the import supply curve approach could be used to provide a coherent interpretation of the remainder of the sentence. In other words, the statute might be read to require an assessment of whether unforeseen shifts of the import supply curve that have induced growth in the volume of imports, were also responsible for having serious injury or threat thereof to a domestic industry. The US statute and Article 4.2 of the SGA can then be seen as mandating a "but for" analysis by the competent authorities, who would need to compare the actual health of the domestic industry with that which would have prevailed but for the change in the conditions of import supply (with all else the same). A safeguard measure would be permitted if and only if the difference between the actual and hypothetical state of the industry was found to be sufficiently great to meet the standard for "serious injury" or threat thereof.

Note that the approach of considering shifts in the import supply curve as the exogenous events that might precipitate injury is distinct from the methods that might be used to carry out the but-for analysis indicated by such an approach. Grossman (1986) has illustrated one possible approach to the counterfactual analysis. He posits a model of the US steel industry in which indicators of industry health are determined by demand trends in the US demand for steel, the aggregate level of industrial production, the world price of iron ore, the world price of energy, and the world price of imported steel. The last of these variables is taken to reflect the location of the import supply curve under the assumption that the United States consumes a relatively small share of the world output of steel. Grossman establishes econometrically a statistical relationship between the indicators of industry 
conditions and current and lagged values of the exogenous variables. He then performs counterfactual simulations to assess how changes in each exogenous variable had contributed to deteriorating conditions in the industry, given the time paths of the others. Grossman was able to evaluate the claim that increased imports of steel (due to changes in import supply conditions) were a substantial cause of injury to the US steel industry by comparing the magnitude of the injury attributable to each factor. Although not conceived for this purpose, his results could also be used to evaluate claims that increased imports resulting from exogenous changes in import supply had caused serious injury to the US industry. Note that the econometric methodology ensures that injury due to other factors besides imports is not attributed to imports; it does so by examining the partial effect of one independent variable on the dependent variable while holding constant the effect of all others.

The econometric methodology proposed by Grossman (1986) is not the only one that might be used to implement the import supply curve approach. Kelly (1988) proposes an alternative method based on the empirical calibration of a simple model of supply and demand for imports and imperfectly-substitutable domestic products. The important point is that the competent authorities should adopt some method that yields a "reasoned and adequate explanation" of the partial effect of changed conditions of import supply on industry health, holding constant the values of other exogenous variables that might also have affected conditions in the domestic industry.

We return now to Line Pipe. Clearly, the $\mathrm{AB}$ did not provide the sort of guidance and interpretation of the statutes that we feel would have been appropriate. Did they also err in finding that the United States had acted inconsistently with its obligation under Article $4.2 \mathrm{~b}$ of the SGA by failing to ensure that injury caused to the domestic industry by factors other than increased imports was not attributed to increased imports? We think not. We have offered two possible interpretations of Article XIX.1 of the GATT, one that treats the exogenous event that might cause injury to a domestic industry as a change in trade policy resulting from obligations incurred under a multilateral agreement and another that treats the exogenous event as a shift in the import supply curve that occurs for any reason. Under either interpretation, Article 4.2b of the SGA still demands objective evidence of a causal relationship that does not attribute to increased imports any injury that may have been caused by other factors. Our reading of the USITC report has been hindered by the censoring done to preserve confidentiality. Still, we find no evidence 
that the USITC carried out the sort of but-for analysis that we would deem necessary for the purpose. For example, nowhere in the document do we find an estimate of the injury caused by any exogenous event related to trade, holding constant the paths of other variables such as the level of oil and gas drilling or the demand for oil country tubular goods. Without such analysis, the USITC could not have ensured that injury caused by these other factors was not attributed to increased imports, the assertions on page I-30 of the report notwithstanding.

\subsection{The allowable extent of a safeguard measure}

On the question of the permissible extent of a safeguard measure, the $A B$ ruled that the words "only to the extent necessary to prevent or remedy serious injury and to facilitate adjustment" in the first sentence of Article 5.1 of the SGA should be read as limiting the extent of a safeguard measure so that it addresses only the serious injury suffered by the industry that can be attributed to increased imports. To reach this conclusion, the $A B$ reflected on whether the "serious injury" referred to in Article 4.2 of the SGA is necessarily the same "serious injury" mentioned in Article 5.1 of the SGA. The AB noted that the Agreement provides only one definition of "serious injury" and does not draw any distinctions in the two references to this term. It inferred from this that the two mentions of "serious injury" must refer to the same underlying concept. The $\mathrm{AB}$ reasoned that, inasmuch as the non-attribution clause modifies the serious injury described in Article 4.2 of the SGA, the same modification must apply to the usage of the term in Article 5.1 of the SGA. The AB concluded that

[i]t would be illogical to require an investigating authority to ensure that the 'causal link' between increased imports and serious injury not be based on the share of injury attributed to factors other than increased imports while, at the same time, permitting a Member to apply a safeguard measure addressing injury caused by all factors.

(para. 252)

We do not agree that such a requirement would somehow be "illogical." As we noted in Section 3, the obligation that injury be linked to external events might reasonably be included as a pre-requisite for safeguard measures in order to address the moral-hazard problem that otherwise would exist if firms could generate protection by their own actions. Once a Member can demonstrate, however, that the poor health of its industry is not (entirely) of its own doing, it might be desirable to allow that Member to counteract 
the full extent of the injury suffered by the industry from all sources. In other words, the reason for insisting on a causal link between increased imports and serious injury can be quite different from the considerations that determine the optimal extent of the consequent remedy.

While we cannot exclude the possibility that the Members intended to allow safeguard measures to offset the full extent of injury by applying logic to the wording of the first sentence of Article 5.1 of the SGA, neither do we see an obvious textual argument to conclude otherwise. If anything, the wording of Article XIX.1a of the GATT would seem to support the interpretation offered by the $\mathrm{AB}$ of Article 5.1 of the SGA. In particular, Article XIX.1a of the GATT allows safeguard measures when a product is being imported "in such increased quantities and such conditions as to cause or threaten serious injury," but only "to the extent and for such time as may be necessary to prevent or remedy such injury..." (emphasis added). The use of the word "such" in the latter clause would seem to refer the interpreter back to the injury attributable to increased imports.

As a matter of economics, there is little we can say about rules regarding the size of safeguard measures without knowing more about the objectives of the Agreement. For example, if the purpose of the SGA is to compensate the losers from trade liberalization, then the applicable safeguard measure should be limited in size to whatever would restore competitive conditions to what they would be but for the relevant changes in trade policy. But if the purpose of the Agreement instead is to encourage restructuring of the domestic industry or to facilitate efficient adjustment, arguably it is the entirety of the injury suffered by the domestic industry that should be used as the basis for tailoring a temporary palliative. An industry that has suffered some injury due to foreign competition and more injury due to other causes will face greater needs for reinvestment and/or adjustment than one that has only suffered from trade competition. If the argument can be made that temporary protection contributes to a more efficient adjustment process, the indicated safeguard measure in the former case may be larger than in the latter. In short, we cannot judge the appropriate size of a safeguard measure from an economic standpoint without knowing what distributive or efficiencyenhancing purpose the measure is intended to serve.

\section{Conclusions}

To conclude, we have argued that the text of the SGA suffers from two serious deficiencies: Article $4.2 \mathrm{~b}$ of the SGA calls for a causality test that 
is economically incoherent and therefore not operational; and the agreement fails to express explicit objectives of the safeguard provisions. With an incoherent text and an absence of clear objectives, it is impossible for the adjudicator to determine when the conditions for a safeguard measure have been satisfied and what is the permissible extent of such a measure.

In the Line Pipe dispute, Korea claimed that the United States had not properly attributed injury to its various causes and that its safeguard measures exceeded in scope what is permitted under the treaty. The $\mathrm{AB}$ ruled against the United States essentially on procedural grounds. It is difficult for us to disagree with the $\mathrm{AB}$ ruling in view of the causal analysis contained in the USITC investigatory report. However, where the $\mathrm{AB}$ embraced the non-attribution requirement in Article $4.2 \mathrm{~b}$ of the SGA, it lent operational significance to an incoherent requirement. To our mind, the $\mathrm{AB}$ ruling in this respect is flawed. The $\mathrm{AB}$ could instead have ruled that after exhausting the interpretative elements proscribed by Articles 31 and 32 of the Vienna Convention on the Law of Treaties, it had reached the conclusion that the legal text lacks an internally consistent interpretation.

Such a ruling would have left the $\mathrm{AB}$ with a dilemma: either it must refrain from ruling in the particular dispute and instead demand of the WTO members that they address, through legislative action, the shortcomings of the text (namely, that imports cannot be a cause of injury inasmuch as they are endogenously determined along with the health of the domestic injury, and so the causality test for a safeguard measure logically can never be met); or it must interpret the text imaginatively so as to render it internally consistent and operational. The first of these alternatives has the merit of respecting the institutional balance between the organs of the WTO, inasmuch as the AB as adjudicator should not be in a position of usurping legislative authority. The disadvantage of this approach, of course, is that until such a time as the WTO Members take corrective action with respect to the incoherent text, the $\mathrm{AB}$ would not be in a position to admit the legality of any safeguard measures. Clearly, the Members intended to permit the use of safeguards in some conditions; without them, the Members might well resort to the use of other instruments of contingent protection in situations that do not fit the "distortions" that the founding fathers meant to address with the SGA.

To avoid such an outcome, we believe that some judicial activism is warranted in the current jurisprudential environment. Our preferred interpretation of the treaty text is the "import supply curve" approach. 
With this approach, the potential cause of injury to a domestic industry is not the increase in the quantity of imports per se (which would be impossible), but rather a shift in the import supply curve that both causes imports to surge and the domestic import-competing industry to suffer. By adopting such an interpretation, the $\mathrm{AB}$ undeniably would be adding words to the SGA that do not exist in the text. However, by doing so, the $\mathrm{AB}$ would be making sense of a conditions test that is poorly described in the SGA but not wholly absent from the SGA. It is clear that the treaty negotiators intended to permit application of safeguards in some but not all circumstances; and the circumstances had to do with the proximate cause of the deterioration of industry conditions. The import supply curve approach is faithful to these intentions.

We emphasize that we do not recommend judicial activism lightly. The Line Pipe dispute and other recent disputes arising from the SGA have two distinctive features. First, the text does indicate that the authors of the agreement intended some limits on the application of safeguard measures and some test for causality. Our interpretation certainly is not contradicted by the text of the agreement. Second, in the absence of some sort of judicial activism, the balance of rights and obligations that was intended by the signatories will be severely undermined. Our preferred approach allows the agreement to be operational, and provides for legal application of safeguard measures, during the period before the text of the SGA is improved.

\section{References}

Baldwin, Richard E. and Robert-Nicoud, Frédéric. 2001. Entry and Asymmetric Lobbying: Why Governments Pick Losers. Manuscript, Graduate Institute for International Studies, Geneva.

Burtless, Gary, Lawrence, Robert Z., Litan, Robert E. and Shapiro, Robert J. 1998. Globaphobia: Confronting Fears About Open Trade. The Brookings Institution: Washington.

Cassing, James H. and Ochs, Jack. 1978. International Trade, Factor Market Distortions, and the Optimal Dynamic Subsidy: Comment. American Economic Review 68, 950-955.

Davidson, Carl and Matusz, Stephen J. 2001. On Adjustment Costs. Manuscript, Michigan State University.

Davidson, Carl and Matusz, Stephen J. 2002. An Overlapping Generations Model of Escape Clause Protection. Manuscript, Michigan State University.

Deardorff, Alan V. 1987. Safeguards Policy and the Conservative Social Welfare Function. pp. 22-40 in H. Kierzkowski, ed., Protection and Competition in 
International Trade: Essay in Honor of W. Max Corden. Blackwell Publishers: Oxford.

Feenstra, Robert C. 1992. How Costly is Protection? Journal of Economic Perspectives 12, 159-178.

Grossman, Gene M. 1986. Imports as a Cause of Injury: The Case of the U.S. Steel Industry. Journal of International Economics 121, 201-223.

Grossman, Gene M. and Helpman, Elhanan. 1994. Protection for Sale. American Economic Review 84, 833-850.

Grossman, Gene M. and Mavroidis, Petros C. 2003. Here Today, Gone Tomorrow? Privatization and the Injury Caused by Non-Recurring Subsidies. A Discussion of the Appellate Body Report on United States - Imposition of Countervailing Duties on Certain Hot-Rolled Lead and Bismuth Carbon Steel Products Originating in the United Kingdom in H. Horn and P.C. Mavroidis, eds., The WTO Case Law of 2001. Cambridge University Press: Cambridge UK.

Horn, Henrik and Mavroidis, Petros C. 2003. What Should be Required of a Safeguard Investigation? A Discussion of the Appellate Body Report On United States Safeguard Measures on Imports of Fresh, Chilled or Frozen Lamb Meat from New Zealand and Australia in H. Horn and P.C. Mavroidis, eds., The WTO Case Law of 2001. Cambridge University Press: Cambridge UK.

Hufbauer, Gary Clyde and Elliot, Kimberly Ann. 1994. Measuring the Costs of Protection in the United States. Institute of International Economics: Washington DC.

Irwin, Douglas A. 2002. Causing Problems? The WTO Review of Causation and Injury Attribution in U.S. Section 201 Cases. NBER Working Paper No. 9815, Cambridge MA.

Kelly, Kenneth. 1988. The Analysis of Causality in Escape Clause Cases. Journal of Industrial Economics, 37, 187-207.

Lapan, Harvey. 1976. International Trade, Factor Market Distortions, and the Optimal Dynamic Subsidy. American Economic Review, 66, 335-346.

Messerlin, Patrick A. 2001. Measuring the Costs of Protection in Europe: European Commercial Policy in the 2000s. Institute of International Economics: Washington DC.

Mussa, Michael. 1982. Government Policy and the Adjustment Process. pp. 73-120 in Jagdish Bhagwati, ed., Import Competition and Response. University of Chicago Press: Chicago.

Mussa, Michael. 1984. The Adjustment Process and the Timing of Trade Liberalization. NBER Working Paper No. 1458, Cambridge MA.

Neary, J. Peter. 1982. Intersectoral Capital Mobility, Wage Stickiness, and the Case for Adjustment Assistance. pp. 39-67 in Jagdish Bhagwati, ed., Import Competition and Response. University of Chicago Press: Chicago.

Rousslang, Donald J. 1988. Import Injury in U.S. Trade Law: An Economic View. International Review of Law and Economics 8, 177-182. 
Sazanami, Yoko, Urata, Shujiro, and Kawai, Hiroki. 1995. Measuring the Costs of Protection in Japan. Institute of International Economics: Washington DC.

Sykes, Alan O. 1991. Protectionism as a 'Safeguard': A Positive Analysis of GATT Escape Clause with Normative Speculations. University of Chicago Law Review, 58, 255-307.

Sykes, Alan O. 2003. The Safeguards Mess: A Critique of WTO Jurisprudence. John M. Olin Law \& Economics Working Paper No. 187 (2D Series), University of Chicago Law School. 